\title{
Por uma Evangelização Integral: Estudo Teológico Pastoral à luz do Magistério Latino Americano
}

\author{
Orientador: Abimar Oliveira de Moraes \\ Mestrando: João Batista Maroni \\ Área de Concentração: Teologia Sistemático-Pastoral
}

Linha de Pesquisa: Fé e Cultura

A Mensagem Cristã, expressa nas Sagradas Escrituras, é portadora de uma concepção unitária e integral da pessoa humana, como também da relação fé e vida.

O dualismo pastoral, entendido como a dicotomia entre fé e vida, que penetrou na ação evangelizadora da Igreja, permanece nela até nossos dias. $\mathrm{Na}$ América Latina e Caribe foram grandes e profundas as conseqüências desse dualismo para a vida do povo e das culturas. As Conferências Episcopais realizadas neste Continente, fiéis à Mensagem Cristã, são garantidoras da concepção integral e unitária do ser humano e da ação evangelizadora da Igreja.

A evangelização integral é a resposta a questão do dualismo pastoral. A Nova Evangelização para a América Latina e Caribe só poderá ser entendida na perspectiva de uma evangelização integral, imperativo para a Igreja e todos os seus Seguimentos Pastorais.

Palavras-chave: Evangelização Integral; Dualismo Pastoral. 